\title{
Clinical profile of Acute Respiratory Distress Syndrome (ARDS) in ICU admitted patients
}

\author{
Sapkal Harish Barsu
}

Assistant Professor, Department of Medicine, Government Medical College, Nagpur, Maharashtra, INDIA. Email: harishsapkal2012@gmail.com

Abstract Background: There are so many critical cases of ARDS admitted in ICU. And there are various different causes of ARDS. There is a rising incidence of ARDS in ICU admitted patients. It is important to identify and control predisposing risk factors at an early stage to prevent the mortality. Aim: To study the clinical profile of Acute Respiratory Distress Syndrome admitted in ICU. Material and Methods: Patients aged 13 years or above admitted in ICU with a diagnosis of ARDS were studied for clinical presentations, risk factors and management outcome

Key Word: Acute Respiratory Distress Syndrome.

\section{*Address for Correspondence:}

Dr Sapkal Harish Barsu, Assistant Professor, Department of Medicine, Government Medical College, Nagpur, Maharashtra, INDIA.

Email: harishsapkal2012@gmail.com

Received Date: 24/04/2020 Revised Date: 13/06/2020 Accepted Date: 02/08/2020

DOI: https://doi.org/10.26611/10211536

This work is licensed under a Creative Commons Attribution-NonCommercial 4.0 International License.

\begin{tabular}{|l|l|}
\hline \multicolumn{2}{|c|}{ Access this article online } \\
\hline Quick Response Code: & Website: \\
& www.medpulse.in \\
& \\
\hline
\end{tabular}

\section{INTRODUCTION}

In critically ill patients ARDS is a common cause of mortality due to respiratory failure, and is defined by the acute onset of noncardiogenic pulmonary edema, need for mechanical ventilation and hypoxemia. There are various causes of ARDS pneumonia, septisemia, aspiration of gastric, oral, or esophageal contents, major trauma, acute pancreatitis, transfusion associated acute lung injury (TRALI),drugs overdose, smoke inhalation, near drowning, shock, high altitude. ARDS is associated with several comorbidities including air pollution ${ }^{1,2}$,alcohol abuse $^{3}$,hypoalbuminemia ${ }^{4}$, and cigarette smoking ${ }^{5}$.ARDS patients are a heterogenous group with variability in clinical presentation and outcome. To reduce this heterogeneity patients with ARDS are subclassified as with
Direct ARDS (pulmonary), and Indirect ARDS (extrapulmonary) ${ }^{6}$

\section{MATERIAL AND METHODS}

This descriptive observational study was carried out in the Department of Medicine of a Tertiary Care Centre in Maharashtra over a period of one year.

Study population: Patients aged 13 years or older admitted to ICU with a diagnosis of Acute Respiratory Distress Syndrome.

Inclusion Criteria: All patients aged 13 years or older admitted with a diagnosis of Acute Respiratory Distress Syndrome. The final diagnosis of ARDS was based on two of the following criteria.

1. Severity: Oxygenation

Mild: $200 \mathrm{mmHg}<\mathrm{PaO} 2 / \mathrm{FiO} 2 \leq 300 \mathrm{mmHg}$

Moderate: $100 \mathrm{mmHg}<\mathrm{PaO} 2 / \mathrm{FiO} 2 \leq 200 \mathrm{mmHg}$

Severe: $\mathrm{PaO} 2 / \mathrm{FiO} 2 \leq 100 \mathrm{mmHg}$

2. Onset : Acute: Within 1 week of a clinical insult or new or worsening respiratory symptoms.

3. Chest radiographs : Bilateral opacities consistent with pulmonary edema not fully explained by effusions, lobar/lung collapse, or nodules.

4. Absence of left atrial hypertension : Hydrostatic edema is not the primary

cause of respiratory failure. If no ARDS risk factor is present, then some objective evaluation is required (e.g., echocardiography) to rule out hydrostatic edema. 


\section{Exclusion Criteria}

- Patients aged $<13$ years

- Those patients 13 years or older with ARDS who refused to give their written informed consent for the study.

- Patient who were not wished to continue in the study after giving the consent.

The patients were interviewed (or their relatives) who were eligible and given such written informed consent. The complete history was taken and the clinical examination was done.

Patients were managed accordingly.

Statistical analysis:

Statistical analysis was carried out with the help of SPSS (version 20) for Windows package (SPSS Science, Chicago, IL, USA).

\section{RESULTS}

Patients belonged to age groups varying from 20 years to 70 years. Majority of patients belonged to age group of 3140 years. Majority were males $(57.14 \%)$, and only 30 patients $(42.85 \%)$ were females. There were 42 patients who had a direct ARDS $(60 \%)$ and 28 patients had Indirect ARDS (40\%). Out of 70 patients, $40 \%$ of patients had DM, $25.71 \%$ patients had HTN, $51.42 \%$ of pts had CKD, $57.14 \%$ CLD, $15.71 \%$ were alcoholic males, $40 \%$ were smokers, $84.28 \%$ had shock. Total number of mild ARDS were $18.57 \%(13)$, moderate ARDS $67.14 \%(47)$, and $14.28 \%$ (10) Severe ARDS. Total deaths were 70\% (49). Maximum deaths $(80 \%)$ were from severe ARDS cases.

* Tables and charts:

Table 1: sex distribution of patients

\begin{tabular}{ccc}
\hline Gender & No. of patients & Percentage (\%) \\
\hline Male & 40 & $57.14 \%$ \\
Female & 30 & $42.85 \%$ \\
\hline Total & 70 & $100 \%$ \\
\hline
\end{tabular}

Table 2: \% Direct and Indirect ARDS cases among males and

\begin{tabular}{ccc}
\multicolumn{3}{c}{ females } \\
\hline & Males & Females \\
\hline Direct ARDS & $23(57.5 \%)$ & $19(63.33 \%)$ \\
Indirect ARDS & $17(42.5 \%)$ & $11(36.66 \%)$ \\
\hline Total & 40 & 30 \\
\hline
\end{tabular}

Table 3: Age wise distribution of no.of cases (\%)

\begin{tabular}{ccc}
\hline Age group & No. of cases & Percentage $\%$ \\
\hline $\begin{array}{c}\text { 21- } 30 \\
\text { years }\end{array}$ & 15 & 21.42 \\
31-40 years & 36 & 51.42 \\
41-50 years & 09 & 12.85 \\
$51-60$ years & 04 & 5.71 \\
$61-70$ years & 06 & 8.57 \\
\hline
\end{tabular}

Table 4: Clinical Outcome

\begin{tabular}{ccc}
\hline & No. of cases & Percentage (\%) \\
\hline Recovered & 21 & $30 \%$ \\
Died & 49 & $70 \%$ \\
\hline Total & 70 & $100 \%$ \\
\hline
\end{tabular}

Table 5: Mortality rates among mild, moderate and severe ARDS

\begin{tabular}{cc}
\hline ARDS severity & Percentage Deaths \\
\hline Mild ARDS & $53.84 \%$ \\
Mod ARDS & $72.34 \%$ \\
Sev ARDS & $80 \%$ \\
\hline
\end{tabular}

Table 6: Severity of ARDS

\begin{tabular}{ccc}
\hline $\mathrm{PaO}_{2} / \mathrm{FiO}_{2}$ (Severity) & No. of patients & Percentage (\%) \\
\hline 200-300 (Mild ARDS) & 13 & $18.57 \%$ \\
100-200 (Mod.ARDS) & 47 & $67.14 \%$ \\
less than 100 (sev.ARDS) & 10 & $14.28 \%$ \\
\hline Total & 70 & $100 \%$ \\
\hline
\end{tabular}

Figure 7: Risk factors of ARDS

\begin{tabular}{ccc}
\hline Risk factors & No. of cases & Percentage \\
\hline CLD & 40 & $57.14 \%$ \\
CKD & 36 & $51.42 \%$ \\
CCF & 53 & $75.71 \%$ \\
HTN & 18 & $25.71 \%$ \\
DM & 28 & $40 \%$ \\
Smoking & 28 & $40 \%$ \\
Alcoholic & 11 & $15.71 \%$ \\
Shock & 59 & $84.28 \%$ \\
\hline
\end{tabular}

\section{DISCUSSION}

Old age is an independent risk factor for ARDS mortality. $7,8,9,10,11,12,13,14,15$ In our study maximum mortality seen in middle aged people.Many studies shows that Dm is associate with a reduced risk of developing ARDS. ${ }^{16,17,18,19}$ But some studies shows there is higher mortality of patients with ARDS and DM. ${ }^{20}$ Some studies shown lower mortality of patients with DM and septic shock. ${ }^{21}$ Some studies shown no significant association of ARDS mortality with DM. ${ }^{22,23,24}$ Our study found no association of DM with ARDS mortality. One study reported that sepsis associated ARDS has increased mortality, severe disease, lower $\mathrm{PaO} 2 / \mathrm{FiO} 2$ ratio. ${ }^{25}$ Present study didn't reported such association. Smoking, alcoholism and Sex all are reported to be associated with mortality with ARDS. ${ }^{26,27,28,29,30,31,32}$ Our study does not reported ARDS mortality association with smoking, alcoholism or sex. LUNG SAFE study reported $34.9 \%$ mortality in mild ARDS, $40 \%$ for those of moderate ARDS, and $46.1 \%$ of severe ARDS. ${ }^{33}$ In our study mortality in mild ARDS was $54 \%$, in moderate ARDS $72 \%$, and in severe ARDS $80 \%$.In our study most of the ARDS patients had some comorbidities rather than pulmonary infections. But in a study of Vigg et al. ${ }^{35}$ shown maximum number of cases from pulmonary infections 
With increasing age there were no statistically significant mortality increase seen in our study, though previous other studies had noted significant increase in mortality with increasing age. However a study conducted by Agarwal et al. ${ }^{34}$ found that there is no significant difference in outcome when compared between young patients and patients with age more than 50 years. Our study shows the corelation between $\mathrm{PaO} 2 / \mathrm{Fio} 2$ ratio at the admission and survival. Patients with ratio 200-300 have better survival, and ratio less than 100 had more deaths. A study performed by P.Squara ${ }^{36}$ shown similar association. Mortality in our study is $70 \%$. A study performed by Agarwal et al. ${ }^{34}$ had mortality of $47.8 \%$. There is no significant difference of mortality between Direct ARDS and Indirect ARDS.

\section{CONCLUSIONS}

Most of the patients with ARDS admitted in ICU were having some previous comorbidities like chronic kidney disease, chronic liver disease, HTN, DM, CCF. So, early intervensions to to control these comorbidities definitely will improve the outcome of ARDS patients. Majority of mortality among studied population in this study was from severe ARDS category. So, $\mathrm{PaO} 2 / \mathrm{FiO} 2$ ratio is an important predictor of mortality in ARDS. It also shown than ventillatory management of ARDS patient is atmost important.

\section{REFERENCES}

1. Ware L B et al.. Long Term Ozone Exposure Increases the Risk of Developing the Acute Respiratory Distress Syndrome. Am J Respir Crit Care Med 193,1143-1150, doi:10.1164/rccm.201507-1418OC(2016). [PubMed:26681363]

2. Reilly JP et al.. Low to Moderate Air Pollutant Exposure and Acute Respiratory Distress Syndrome after Severe Trauma. Am J Respir Crit Care Med, doi:10.1164/rccm.201803-0435OC(2018)

3. Moss M, Bucher B, Moore F A, Moore E E and Parson PE, The role of chronic alcohol abuse in the development of acute respiratory distress syndrome in adults, JAMA 275, 50-54(1996). [PubMed:8531287]

4. Mangialardi RJ et al.. Hyponatremia predicts acute respiratory distress syndrome development, weight gain and death in patients sepsis. Ibuprofen in Sepsis Study Group. Crit Care Med 28, 3137-3145 (2000). [PubMed 11008971]

5. Calfee CS et al. Active and passive cigarette smoking and acute lung injury after severe blunt trauma. Am J Respir Crit Care Med 183, 1660-1665, doi:10.1164.rccm.2010111802OC(2011).[PubMed:21471091]

6. Calfee CS et al.. Cigarette Smoke Exposure and the Acute Respiratory Ristress Syndrome. Crit Care Med 43, 1790 1797, (2015).[PubMed:26010690]

7. Seeley E, McAuley DF,Eisner M, et al.. Predictors of moertality in acute lung injury during the era of lung protective ventilation. Thorax 2008;63(11):994-998.
8. Gong MN, Thompson BT, William P, ET AL.. Clinical predictors of and mortality in acute respiratory distress syndrome: potential role of red cell transfusion. Crit Care Med. 2005;33(6):1191-1198.

9. Sigurdsson MI, Sigvaldson k, Gunnarsson TS, et al. . Acute Respiratory Distress Syndrome; nationwide changes in incidence, treatment and mortality over 23 years. Acta Anaesthesiol Scand. 2013;57(1):37-45.

10. Zilberberg MD, Epstein SK. Acute Lung Injury in the medical ICU: comorbid conditions, age, etiology and hospital outcome. Am J Respir Crit Care Med. 1998:157(4 pt 1):1159-1164.

11. Suchyta MR, Clemmer TP, Elliotte CG, et al. The adult respiratory distress syndrome. A report of survival and modifying factors. Chest. 1992;101(4):1074-1079.

12. Fowler AA, Hamman RF, Good JT, et al.. Adult Respiratory Distress Syndrome: risk with common predispositions. Ann Intern Med. 1983;98(5 pt 1);593-597.

13. Schimicki CN, Biehl M, Wilson GA, et al. . Comparison of hospital mortality and long term survival in patients with Acute lung injury/ARDS vs cardiogenic pulmonary edema. Chest. 2015;147(3);618-625.

14. Ware LB, Koyama, Billheimer DD, et al.. Prognostic and pathogenetic value of combining clinical and biochemical indices in patients with acute lung injury. Chest. 2010;137(2): 288-296.

15. Leucke T, Muench e, Roth H, et al.. Predictors of mortality in ARDS patients referred to a tertiary care centre:a pilot study, Eur J Anaesthesiol. 2006;23(5);403-410.

16. Yu S, Christiani DC, Thompson BT, et al.. Role of diabetes in acute respiratory distress syndrome. Crit Care Med. 2013;41(12):2720-2732.

17. Moss M, Guidot DM, Steinberg KP, et al.. Diabetic patients have a decreased incidence of acute respiratory distress syndrome. Crit Care Med. 2000;28(7):2187-2192.

18. Honiden S, Gong MN. Diabetes, Insulin and development of acute lung injury. Crit Care Med. 2009;37(8):24552464.

19. Gong MN, Thompson BT, William P, ET AL.. Clinical predictors of and mortality in acute respiratory distress syndrome: potential role of red cell transfusion. Crit Care Med. 2005;33(6):1191-1198.

20. Koh GC, Vlaar AP, Hofstra JJ, et al.. In the critically ill patient diabetes predicts mortality independent of statin therapy but is not associated with acute lung injury: a cohort study. Crit Care Med. 2012;40(6): 1835-1843.

21. Moss M, Guidot DM, Steinberg KP, et al.. Diabetic patients have a decreased incidence of acute respiratory distress syndrome. Crit Care Med. 2000;28(7):2187-2192.

22. Yu S, Christiani DC, Thompson BT, et al.. Role of diabetes in acute respiratory distress syndrome. Crit Care Med. 2013;41(12):2720-2732.

23. Singla A, Turner P, Pendurthi MK, et al.. Effect of type II diabetes mellitus on outcomes in patients with acute respiratory distress syndrome. J Crit Care. 2014;29(1): 6669.

24. Saubani AO, Chen W, Jang H. The outcome of acute respiratory distress syndrome in relation to body mass index and diabetes mellitus. Heart Lung. 2015;44(5):441447. 
25. Sheu CC, Gong MN, Zhai r, et al.. Clinical characteristics and outcomes of sepsis related vs non-sepsis-related ARDS. Chest. 2010;138(3): 559-567.

26. Carey MA, Card JW, Voltz JW, et al.. The impact of sex and sex hormones on lung physiology and disease. Am J Physiol Lung Cell Mol Physiol.2007;293(2):L272-L278.

27. Moss M, Mannino DM. Race and gender differences in acute respiratory distress syndrome deaths in United States; an analysis of multiple cause mortality data (199791996). Crit Care Med. 2002;30(8):1679-1685.

28. Perelman RH, Palta M, Kirby R, et al.. Discordance between male and female deaths due to acute respiratory distress syndrome. Pediatrics. 1986;78(2):238-244.

29. Lingappan K, Srinivasan C, Jiang W, et al. Analysis of the transcriptome in hyperoxic lung injury and sex specific alterations in gene expression. PLoS One. 2014;9(7):e101581.

30. Moss M, Bucher B, Moore FA, et al. Role of chronic alcohol abuse in the development of acute respiratory distress syndrome in the adults. JAMA. 1996;275(1):5054.

31. Moss M, Parson PE, Steinberg KP, et al..Chronic alcohol abuse is associated with an increased incidence of acute respiratory distress syndrome and severity of multiple organ dysfunction in patients with septic shock. Crit Care Med. 2003;31(3):869-877.

32. Calfee CS, Matthay MA, Kangelaris KN, et al.. Cigarette smoke exposure and the acute respiratory distress syndrome. Crit Care Med. 2015;43(9):1790-1797.

33. Cortegiani A, et al.. Immunocompromised patients with acute respiratory distress syndrome: secondary analysis of the LUNG SAFE database. Crit Care 22, 157, doi:10.1186/s13054-018-2079-9(2018). [PubMed:29895331].

34. Ritesh Agarwal, Ashutosh N. Agarwal, Dheeraj Gupta et al. Etiology and outcomes of Pulmonary and Extrapulmonary Acute Lung Injury/ARDS in Respiratory ICU in North India. Chest. 2006;130;724-729.

35. A Vigg, S Mantri, Avanti Vigg, A Vigg. Clinical profile of ARDS. JAPI 2003;51;855-858.

36. P Squara, J-F A Dhainant, A Artigar, J Carlet, and Europian collaborative ARDS working group. Haemodynamic profile in severe ARDS; results of Europian collaborative ARDS Study. Intensive Care Med. 1998;24;1018-1028.

\section{Source of Support: None Declared Conflict of Interest: None Declared}

Policy for Articles with Open Access:

Authors who publish with MedPulse International Journal of Medicine, Print ISSN: 2550-7583, Online ISSN: 2636-4751 agree to the following terms: Authors retain copyright and grant the journal right of first publication with the work simultaneously licensed under a Creative Commons Attribution License that allows others to share the work with an acknowledgement of the work's authorship and initial publication in this journal. Authors are permitted and encouraged to post links to their work online (e.g., in institutional repositories or on their website) prior to and during the submission process, as it can lead to productive exchanges, as well as earlier and greater citation of published work. 